\title{
SOFT SKILLS MODEL BASED SCHOOL CULTURE TO DEVELOPMENT STUDENT CHARACTER FOR ELEMENTARY SCHOOL STUDENTS
}

\section{Umi Handayani, Sri Utaminingsih, Slamet Utomo}

Universitas Muria Kudus, Indonesia

Email: handayaniumi999@gmail.com

\begin{tabular}{|c|c|}
\hline Info Artikel & Abstract \\
\hline Sejarah Artikel: & $\begin{array}{l}\text { This study aims to develop a soft skills model based school culture for character education } \\
\text { for elementary school students. }\end{array}$ \\
\hline Diserahkan 12 Oktober 2019 & This study is a Research and Development study with a modified Sugiyono model. This \\
\hline Direvisi 5 Agustus 2020 & research was conducted in 3 elementary schools in the target area of III, Jekulo District, \\
\hline Direvisi 21 Agusutus 2020 & Kudus Regency. Data collection techniques using test techniques and non-test techniques. \\
\hline Disetujui 28 November 2020 & $\begin{array}{l}\text { Data analysis in this study was carried out descriptively quantitative and statistical tests } \\
\text { using t-test. }\end{array}$ \\
\hline $\begin{array}{l}\text { Keywords: } \\
\text { soft skills, } \\
\text { characters, } \\
\text { school cultures }\end{array}$ & $\begin{array}{l}\text { The results of the research were in the form of a soft skills model design product based on } \\
\text { school culture which had components of goal setting, soft skill values, school culture and } \\
\text { character education. The soft skills model based on school culture is suitable for use as a } \\
\text { learning model in elementary schools. The results of the t test show that } t \text { count }>\text { t table, } \\
\text { so that the soft skills model based on school culture is effectively applied in learning. }\end{array}$ \\
\hline
\end{tabular}

\begin{abstract}
Abstrak
Penelitian ini bertujuan mengembangkan model softskills berbasis budaya sekolah untuk pendidikan karakter siswa sekolah dasar.

Penelitian ini merupakan penelitian Research and Development dengan model Sugiyono yang telah dimodifikasi. Penelitian ini dilakukan di 3 Sekolah Dasar Daerah Binaan III Kecamatan Jekulo Kabupaten Kudus. Teknik pengambilan data dengan manggunakan teknik tes dan teknik non tes. Analisis data dalam penelitian ini dilakukan secara deskriptif kuantitatif dan uji statistik dengan menggunakan uji-t.

Hasil penelitian berupa produk Desain model soft skills berbasis budaya sekolah yang memiliki komponen penyusunan tujuan, nilai-nilai soft skill, budaya sekolah dan pendidikan karakter. Model soft skills berbasis budaya sekolah layak digunakan sebagai model pembelajaran di Sekolah Dasar. Hasil uji t menunjukkan bahwa t hitung $>\mathrm{t}$ tabel, sehingga model soft skills berbasis budaya sekolah efektif diterapkan dalam pembelajaran.
\end{abstract}


Umi Handayani, Sri Utaminingsih, Slamet Utomo

SOFT SKILLS MODEL BASED SCHOOL CULTURE TO DEVELOPMENT STUDENT ...

REFLEKSI EDUKATIKA : Jurnal Ilmiah Kependidikan, Volume 11, Nomor 1, Desember 2020, hlm. 1-7

\section{INTRODUCTION}

The development of the character of a nation is one of the main concerns of the government. Character building must be integrated and become an integrated part of the learning process that does not stand alone separately. This is as mandated by Law No. 20 of 2003 on the National Education System in article 3 which states that national education has the function of developing capabilities and shaping dignified national character and civilization in the context of educating the nation's life.

Character education must be developed as a whole within the framework of the National Education System in order to achieve the goals of National Education. The existence of character education is an effort to help the mental development of children both physically and mentally towards a human and better civilization (Fakhriyah, Roysa, and Sumaji, 2014; Ismaya and Romadlon, 2017; Pratiwi and Kuryanto, 2019; Widyatmoko, 2019). Character education must foster and develop philosophical values and practice the entire character of the nation as a whole and comprehensively. Character education must also contain the glue of a nation that has various cultures in the form of awareness, understanding and cultural intelligence of the community. In addition, character education has a higher meaning than moral education, because it is not only related to the problem of right from wrong, but how to instill habits about the good things in life, so that students have high awareness and understanding, as well as concern and commitment. to practice virtue in everyday life.

Character is a person's nature in responding to situations morally, which is manifested in real action through good behavior, honesty, responsibility, respect for others, and other noble character values. This is in line with Aristotle's expression, that character is closely related to "habits" or habits that are continually practiced and practiced. Ardianti, et al (2017) also revealed that character will be formed through repeated behavior. Character is not limited to knowledge. Someone who has good knowledge is not necessarily able to act according to his knowledge, if he is not trained (becomes a habit) to do that good. Character also reaches into the emotional and habitual areas of the self.
The character possessed by a person has more or less influence on the formation of soft skills. In line with the research results of Ratnawati (2016) that character education is proven to provide a positive contribution to soft skills. Djamaris (2016) also states that in its development, soft skills are largely contributed by personal character from being educated in the family environment (parenting), traditions and influences from the school / social environment. Soft skills themselves are emotional and social intelligence (Emotional Intelligence Quotient) which is very important to complement hard skills or intellectual intelligence (Intelligence Quotient). According to Aly (2017) the ideal education in Indonesia is to combine hard skills and soft skills.

Soft skills concern a person's personal character which can improve individual interactions, job performance and career prospects. Soft skills as a form of behavioral competence are known as interpersonal skills or people skills, which include communication skills, conflict resolution and negotiation, personal effectiveness, creative problem solving, strategic thinking, team building, influencing skills and selling skills (ideas or ideas).

The development of a soft skills model is important for character education, especially for elementary school aged children. The objectives of developing the soft skills model include (1) developing the intellectual life of the nation, (2) shaping character, (3) forming a dignified national civilization, (4) forming character building. The value of the soft skills developed is the domain that is assessed including thinking (knowing good), feeling (feeling good), and everyday behavior (action good).

Basically, children's character education is determined by the basic inheritance / family descent, then developed in the neighborhood (social environmental), cultural environment (cultural environment), and the natural environment (natural environment). The development of a soft skills model based on school culture for character education is believed to be necessary and important for schools and their stakeholders to do. This needs to be done as a foothold in implementing character education that can have an impact on the soft skills of elementary school students to achieve success in the future. a person's success is not determined solely by knowledge and technical abilities (hard 
Umi Handayani, Sri Utaminingsih, Slamet Utomo

SOFT SKILLS MODEL BASED SCHOOL CULTURE TO DEVELOPMENT STUDENT ...

REFLEKSI EDUKATIKA : Jurnal Ilmiah Kependidikan, Volume 11, Nomor 1, Desember 2020, hlm. 1-7

skills), but rather by the ability to manage oneself and others (soft skills). Success is only determined around 20 percent by hard skills and the remaining 80 percent by soft skills (Kompasiana, 2015).

The purpose of this study was to develop a soft skills model based school culture for character education for elementary school students.

\section{METHOD}

The type of research used in this research is Research and Development ( R \& D). This development research step refers to Sugiyono (2013), with a modification of taking 7 research steps due to limited time, energy, and costs in research. The steps of this research include 1) potential and problems, 2) data collection, 3) product design, 4) product validation, 5) product revision, 6) product testing, and 7) product revision. This research was conducted in 3 elementary schools in the target area of III, Jekulo District, Kudus Regency.

Data collection techniques using test techniques and non-test techniques. The test technique uses the pretest and posttest question instruments. Non-test techniques include interviews, observations, and questionnaires with research instruments used including validation sheets, questionnaires, interview guideline sheets, and observation guideline sheets. The data analysis in this research was carried out by descriptive quantitative and statistical tests using the t-test.

\section{RESULT AND DISCUSSION Needs Analysis}

The initial stage in this development research is to carry out needs analysis activities. Analysis of needs in this study was carried out through observation, interviews, and questionnaires conducted at 3 elementary schools, namely SD 3 Terban, SD 4 Terban, and SD 1 Jekulo. The results of the observation of the needs analysis for developing a soft skills model based on school culture are presented in the following table.
Table 1. Result of Observastion

\begin{tabular}{|c|l|c|}
\hline No & \multicolumn{1}{|c|}{ Aspect } & $\begin{array}{c}\text { Average } \\
\text { score }\end{array}$ \\
\hline 1 & $\begin{array}{l}\text { Students' enthusiastic attitude } \\
\text { towards learning }\end{array}$ & 2,88 \\
\hline 2 & Student activeness in learning & 2,70 \\
\hline 3 & $\begin{array}{l}\text { Student interaction with } \\
\text { teachers and friends }\end{array}$ & 3,16 \\
\hline 4 & Students' skills using models & 2,70 \\
\hline 5 & $\begin{array}{l}\text { Students are able to carry out } \\
\text { the tasks given by the teacher }\end{array}$ & 2,54 \\
\hline
\end{tabular}

Based on Table 1, it is known that the average score for each aspect is less than 3, this means that the score is in the sufficient category. Furthermore, interviews were conducted with students and teachers. The interview was conducted to determine the need for the development of soft skills media based on the sacred school culture in general. The interview guide consisted of 11 questions for the soft skills needs analysis based on school culture in Kudus.

Based on the results of the needs analysis interview, students stated that they needed soft skills based on school culture. The soft skills based on school culture that are needed are cultural traits / characters in schools that must be instilled from an early age, from entering the school gate to saying greetings, the value of honesty, responsibility, independence, and it can be seen from the various characters of students from one another, so that latent talent can emerge character / character. Interviews were also conducted with teachers. The results of the interview with the teacher's needs analysis showed that soft skills based on school culture were needed and the soft skills method was needed to foster student character.

Needs analysis was also performed using a questionnaire instrument. Data regarding media needs is obtained through a questionnaire to determine the desired needs. Based on the results of the student needs analysis questionnaire, it was found that the teacher rarely used the method when learning. Often uses live lectures. Therefore, a method is needed that can make it easier for students to receive character material. The results of the questionnaire revealed that the soft skills desired were the development of character traits in strengthening character education that were embedded in the minds of students to form their soul. Latent talents could emerge with character education. 


\section{Umi Handayani, Sri Utaminingsih, Slamet Utomo SOFT SKILLS MODEL BASED SCHOOL CULTURE TO DEVELOPMENT STUDENT ... \\ REFLEKSI EDUKATIKA : Jurnal Ilmiah Kependidikan, Volume 11, Nomor 1, Desember 2020, hlm. 1-7}

\section{Product Design}

The product developed is a soft skills model which includes the formulation of objectives, determining the values of soft skills to be developed, and a soft skills component. The soft skills model design based on school culture for character education that is developed consists of the following components.

a. The purpose of developing soft skills

b. Soft skills developed include; critical thinking, creative thinking, communicating clearly, listening, acting assertively, and finding conflict resolution, which are briefly called academic skills and social skills

c. The school culture consists of the school and the environment

d. Learning consists of lesson plans and comprehensive methods which include inculcation, modeling, facilitation, and skill building.

e. The implementation of character education, learning planning needs to be developed to coordinate the character that will be formed with other learning components, namely competency standards and basic competencies, standard materials, indicators of learning outcomes, and assessment.

In the success of character education in schools, ideally students are involved in planning, to identify types of characters, establish standard materials, develop learning outcome indicators, and conduct assessments. Meanwhile, they can determine the type of assessment to see the success and progress of their learning. The involvement of these students, among others, can be done through group discussions, reflection, and brainstorming

\section{Product Validation}

Product validation is carried out in 2 stages, namely material validation and model validation. Material validation was carried out by Mr. Dr. Murtono, M.Pd. lecturer in Master of Basic Education at Muria Kudus University. Material validation includes an assessment of the product in terms of material content and learning aspects. The recapitulation of the results of the material expert's validation is presented in Table 2.

Table 2. Validation Result From Material Expert

\begin{tabular}{|c|c|c|}
\hline No & Aspect & Score \\
\hline 1 & Suitability of content & 12 \\
\hline 2 & Use of models & 7 \\
\hline \multicolumn{2}{|c|}{ Toral Score } & 19 \\
\hline & Average & 3,8 \\
\hline
\end{tabular}

The results of the first stage material expert's assessment obtained a total score of 19 with an average of 3.8. Based on the guidelines for the conversion of quantitative to qualitative data, the soft skills model development is in the very good category. At this stage, the material expert responded to the soft skills model to be validated by the model expert. The results of the model expert validation are presented in Table 3 below.

Table 3. Validation Result From Model Expert

\begin{tabular}{|c|l|c|}
\hline No & Aspect & Score \\
\hline 1 & Soft skills cover & 6 \\
\hline 2 & Soft skills modeling & 6 \\
\hline 3 & Content & 11 \\
\hline \multicolumn{2}{|c|}{ Toral Score } & 23 \\
\hline \multicolumn{2}{|c|}{ Average } & 3,3 \\
\hline
\end{tabular}

The results of the model expert's assessment obtained a total score of 23 with an average of 3.3 which means that the model is in the good category but needs improvement. Based on the guidelines for the conversion of quantitative to qualitative data, the soft skills model is in the good category.

\section{Product Trial}

Products developed after being validated by experts and made improvements, are then tested on a large scale. Product trials were carried out on fifth grade students in 3 elementary schools, namely SD 3 Terban, SD 4 Terban, and SD 1 Jekulo. The following is a recapitulation of pretest and poststest scores with the soft skills model based on school culture. 
Umi Handayani, Sri Utaminingsih, Slamet Utomo

SOFT SKILLS MODEL BASED SCHOOL CULTURE TO DEVELOPMENT STUDENT ...

REFLEKSI EDUKATIKA : Jurnal Ilmiah Kependidikan, Volume 11, Nomor 1, Desember 2020, hlm. 1-7

Table 4. Recapitulation of Pretest dan Posstest Result

\begin{tabular}{|l|c|c|c|c|c|c|}
\hline \multirow{2}{*}{ Aspect } & \multicolumn{3}{|c|}{ Pretest } & \multicolumn{3}{c|}{ Posttest } \\
\cline { 2 - 7 } & $\begin{array}{c}\text { SD 3 } \\
\text { Terban }\end{array}$ & $\begin{array}{c}\text { SD 4 } \\
\text { Terban }\end{array}$ & $\begin{array}{c}\text { SD 1 } \\
\text { Jekulo }\end{array}$ & $\begin{array}{c}\text { SD 3 } \\
\text { Terban }\end{array}$ & $\begin{array}{c}\text { SD 4 } \\
\text { Terban }\end{array}$ & $\begin{array}{c}\text { SD 1 } \\
\text { Jekulo }\end{array}$ \\
\hline Ave rage & 76,16 & 76,30 & 72,18 & 82,06 & 82,89 & 82,89 \\
\hline Max score & 93 & 93 & 93 & 96 & 96 & 96 \\
\hline Min score & 53 & 67 & 53 & 56 & 64 & 64 \\
\hline
\end{tabular}

Based on Table 3, it is known that there is an increase in the pretest and posttest scores of students in the three elementary schools. Furthermore, the statistical test is carried out, namely the $t$ test to determine the effectiveness of the application of the soft skills model statistically.

Based on the t test in three schools, it was obtained tcount $>$ ttable. The $t$ test in SD 3 Terban obtained $\mathrm{t}$ count of 4.288 while $\mathrm{t}$ table $=1.69$, then $\mathrm{Ha}$ is accepted and $\mathrm{H} 0$ is rejected so that the soft skills model is declared effective. While the $\mathrm{t}$ test value at SD 4 Terban is obtained $\mathrm{t}$ count $=$ $2.177>\mathrm{t}$ table $=1.73$, then $\mathrm{Ha}$ is accepted and $\mathrm{H} 0$ is rejected so that the use of the soft skills model is effective. The t test at SD 1 Jekulo is obtained $\mathrm{t}$ count $=2.371>\mathrm{t}$ table $=1.169$, then $\mathrm{Ha}$ is accepted and $\mathrm{HO}$ is rejected so that the use of the soft skills model is effective. Based on the results of the $\mathrm{t}$ test, it can be concluded that there is effectiveness in using the soft skills model in SD 3 Terban, SD 4 Terban, and SD 1 Jekulo.

The development of a soft skills model based on school culture to improve the character of elementary school students has components of goal setting, the values of the soft skills developed, school culture and character education. Soft skills are the characteristics of each individual in the form of skills in dealing with other people and skills in managing themselves. When we talk about soft skills, we are also talking about individual character.

Individual character is formed according to individual behavior which is carried out repeatedly. According to James Stenson in Lickona (2012) states that children develop character through what they see, what they hear, and what they repeatedly do. A supportive environment for children to behave well continuously will form a good character in children. The school environment is an environment where children interact. According to Zuchdi, et al (2010) character education can be effective if it is accompanied by the development of habits or culture in schools. In addition, Ardianti, et al (2019) stated that education which is based on strong cultural principles will make students not easily influenced by external cultures, so that they are able to consider whether or not the outside culture is good.

School culture is a set of values that underlie behavior, traditions, daily habits, and symbols practiced by school principals, educators / teachers, educational / administrative personnel, students, and the community around the school. The school culture used in this study includes entering the school gate saying greetings, the value of honesty, responsibility, and independence. The school culture that is used as the daily behavior of students at school will help form noble character in students, so that education in primary schools is not only in the form of knowledge (hard skills) but also soft skills. This is supported by the opinion of Rusmadiana (2016) which states that education that should be received by elementary school students is not only given in the form of hard skills but also sensitivity in soft skills. In line with the opinion of Paryati (2017) that the development of soft skills in elementary school age children is important because it relates to interactions in the environment.

The soft skills model developed was tested statistically to determine its effectiveness. The results of the test on the effectiveness of the soft skills model based on school culture showed positive results on the achievement of fifth grade students at SD 3 Terban, SD 4 Terban, and SD 1 Jekulo. The results showed an increase in student test scores after the application of the soft skills model based on school culture. The increase in test scores that occurred in grade $\mathrm{V}$ students in the three elementary schools was due to the students doing active learning activities with the soft skills model developed. The results of this study are reinforced by the results of research by Purmintasari (2013), Mahfud (2014) Ahmadi et al (2017), Rachman et. al (2017), Kusumadewi (2019). Ahmadi et al (2017) says that the use of 
Umi Handayani, Sri Utaminingsih, Slamet Utomo

SOFT SKILLS MODEL BASED SCHOOL CULTURE TO DEVELOPMENT STUDENT ...

REFLEKSI EDUKATIKA : Jurnal Ilmiah Kependidikan, Volume 11, Nomor 1, Desember 2020, hlm. 1-7

the soft skills model is effective in improving student learning outcomes. The application of the soft skills model involves the learning media used. The use of this media also has an impact on increasing student test scores. Purmintasari (2013) states that the effectiveness of soft skills media in social studies subjects shows higher results than the use of pictorial story media. These results indicate that the media in the soft skills model developed has an effect on classroom learning, especially for elementary school students. This opinion is in line with Mahfud (2014) that the ability of the soft skills aspect of students can develop well through several character education programs. This can be shown by student achievement.

Kusumadewi (2019) says The results of the effectiveness test show that "Curriculum Management Based on Strengthening Character Education for Improving the Quality of Learning in Elementary Schools is effectively used in learning in Class IV Elementary Schools Theme "Beautiful Togetherness" Sub Theme 1 "Diversity of My Nation's Culture" with the average results of individual completeness in Masehi Elementary School reaches 91\%, while in Tanwirul Qulub Elementary School and 2 nd Panjunan Elementary School reached 82\%.

\section{CONCLUSION}

1. The design of the soft skills model based on school culture has components of goal setting, soft skill values, school culture and character education

2. The soft skills model based on school culture is appropriate for use as a learning model in elementary schools

3. The results of the $t$ test show that $t$ count $>t$ table, so that the soft skills model based on school culture is effectively applied in learning.

\section{REFERENCES}

Ahmadi, F., Sutaryono, Witanto, Y., \& Ratnaningrum, I. 2017. Pengembangan Media Edukasi "Multimedia Indonesia Culture" (MIC) sebagai Penguatan Pendidikan Karakter Siswa Sekolah Dasar. Jurnal Penelitian Pendidikan, 34 (2): 127-135.
Aly, A. 2017. Pengembangan Pembelajaran Karakter Berbasis Soft Skills Di Perguruan Tinggi. Ishraqi, 1 (1): 18-30.

Ardianti, S.D., Wanabuliandari, S., dan Rahardjo, S. 2017. Peningkatan Perilaku Peduli Lingkungan dan Tanggung Jawab Siswa Melalui Model EJAS Dengan Pendekatan Science Edutainment. Jurnal Ilmiah Pendidikan Dasar, 4 (1): 1-7.

Ardianti, S.D., Wanabuliandari, S., dan Kanzunnudin, M. 2019. Implementasi Pembelajaran Berbasis EthnoEdutainment Untuk Meningkatkan Karakter Cinta Tanah Air Siswa Sekolah Dasar. Refleksi Edukatika: Jurnal Ilmiah Kependidikan, 9 (2): 204-209.

Djamaris. 2016. Analisis Faktor Kompetensi Soft Skills Mahasiswa yang Dibutuhkan Dunia kerja Berdasarkan Persepsi Manajer dan HRD Perusahaan. https://www.researchgate.net/profile/Auri no_Djamaris/publication/.

Fakhriyah, Fina., Roysa, Mila., dan Sumaji. 2014. Penerapan Pembelajaran Tematik Berwawasan Multiple Intellegence Dalam Upaya Membentuk Karakter Siswa Di SD IT Al Islam Kudus. Refleksi Edukatika: Jurnal Ilmiah Kependidikan, 4 (1).

Ismaya, Erik Aditia., dan Romadlon, Farid Noor. 2017. Strategi Membentuk Karakter Semangat Kebangsaan Anggota Ambalan Kyai Mojo dan Nyi Ageng Serang. Refleksi Edukatika: Jurnal Ilmiah Kependidikan, 7 (2): 140-144.

Kompasiana. 2015. Sukses: 20\% skills, 80\% attitude!.

https://www.kompasiana.com/errysunarli/ sukses-20-skills-80-attitude. Diakses pada September 2017

Kusumadewi, Subekti. 2019. Pengembangan Model Manajemen Kurikulum Berbasis Penguatan Pendidikan Karakter Untuk Meningkatkan Mutu Pembelajaran Di Sekolah Dasar. Refleksi Edukatika : Jurnal Ilmiah Kependidikan, 10 (1): 8796 
Umi Handayani, Sri Utaminingsih, Slamet Utomo SOFT SKILLS MODEL BASED SCHOOL CULTURE TO DEVELOPMENT STUDENT ...

REFLEKSI EDUKATIKA : Jurnal Ilmiah Kependidikan, Volume 11, Nomor 1, Desember 2020, hlm. 1-7

Lickona, T. 2012. Character Matters. Jakarta: Bumi Aksara.

Mahfud, M. 2014. Program Pendidikan Karakter dan Pemaknaan Pengembangan Soft Skills di SMK NU Gresik. Jurnal Kebijakan Dan Pengembangan Pendidikan, 2 (2).

Paryanti, D. 2017. Peningkatan Soft Skills Pada Pembelajaran Tematik-Integratif Kompetensi IPA Melalui Metode Inquiry Di Kelas V. Jurnal Prima Edukasia, 5 (1): $35-46$

Pratiwi, Ika Ari., dan Kuryanto, Mohammad Syaffruddin. 2019. Correlation Betengan Traditional Games On Locomotor Movements And Characters. Refleksi Edukatika : Jurnal Ilmiah Kependidikan, 10 (1): 71-76.

Purmintasari, Y.D. 2013. Pengembangan Media Buku Ilustrasi Pop-Up Sejarah Dalam Pembelajaran IPS Di Sekolah Dasar. (Tesis). Surakarta: Program Pascasarjana Universitas Sebelas Maret.
Rachman, Maman., Masrukhi, M., Munandar, Aris dan Suhardiyanto, Andi. 2017. Pengembangan Model Manajemen Pelatihan Dan Pengembangan Pendidikan Karakter Berlokus Padepokan Karakter. Refleksi Edukatika : Jurnal Ilmiah Kependidikan, 8 (1): 16-26.

Ratnawati, D. R. 2016. Kontribusi Pendidikan Karakter dan Lingkungan Keluarga terhadap Soft Skill Siswa SMK. Tadris: Jurnal Keguruan Dan Ilmu Tarbiyah, 1 (1): 23-32.

Rusmardiana, A. 2016. Soft Skills Terhadap Karakter Siswa Sekolah Dasar. Faktor Jurnal Ilmiah Kependidikan, 3 (2): 97104.

Sugiyono. 2013. Metode Penelitian. Bandung: CV Alfabeta.

Undang-Undang Republik Indonesia Nomor 20 Tahun 2003 tentang Sistem Pendidikan Nasional.

Widyatmoko, Herwin. 2019. The Development Of Educational Puzzle Game Based on The Local Wisdom Using Flash Media to Educate The Students' Characteristic of Primary School. Refleksi Edukatika : Jurnal Ilmiah Kependidikan, 9 (2): 192198.

Zuchdi, D., Prasetya, Z.K., dan Masruri, M.S. 2010. Pengembangan Model Pendidikan Karakter Terintegrasi dalam Pembelajaran Bidang Studi Di Sekolah Dasar. Cakrawala Pendidikan, (3): 1-12. 